Federal Reserve Bank of Dallas

Globalization and Monetary Policy Institute

Working Paper No. 295

http://www.dallasfed.org/assets/documents/institute/wpapers/2017/0295.pdf

\title{
Oil Price Shocks and Policy Uncertainty: New Evidence on the Effects of US and non-US Oil Production*
}

\author{
Wensheng Kang \\ Kent State University \\ Ronald A. Ratti \\ Western Sydney University \\ Joaquin L. Vespignani \\ University of Tasmania
}

January 2017

\begin{abstract}
Important interaction has been established for US economic policy uncertainty with a number of economic and financial variables including oil prices. This paper examines the dynamic effects of US and non-US oil production shocks on economic policy uncertainty using a structural VAR model. Such an examination is motivated by the substantial increases in US oil production in recent years with implications for US political and economic security. Positive innovations in US oil production are associated with decreases in US economic policy uncertainty. The economic forecast interquartile ranges about the US CPI and about federal/state/local government expenditures are particularly sensitive to innovations in US oil supply shocks. Shocks to US oil supply disruption causes rises in the CPI forecast uncertainty and accounts for $21 \%$ of the overall variation of the CPI forecaster disagreement. Dis-aggregation of oil production shocks into US and non-US oil production yield novel results. Oil supply shocks identified by US and non-US origins explain as much of the variation in economic policy uncertainty as structural shocks on the demand side of the oil market.
\end{abstract}

JEL codes: E44, G12, Q43

\footnotetext{
* Wensheng Kang, Kent State University, Department of Economics, 800 E. Summit St., Kent, OH 44240. 330-308-7414. wkang3@kent.edu. Ronald A. Ratti, Western Sydney University, School of Business, Australia.+61-2-96859346. r.ratti@westernsydney.edu.au. Joaquin L. Vespignani, University of Tasmania, School of Business and Economics, Australia. +61-3-62262825. The views in this paper are those of the authors and do not necessarily reflect the views of the Federal Reserve Bank of Dallas or the Federal Reserve System.
} 


\section{Oil Price Shocks and Policy Uncertainty: New Evidence on the Effects of US and non-US}

\section{Oil Production}

\section{Introduction}

Baker et al. (2016) construct an index of economic policy uncertainty and show that it influences the business cycle and business investment. Research building on the contributions by Bloom (2009) and Baker et al. (2016) has established that economic policy uncertainty has significant implications for economic and financial activity. ${ }^{1}$ Following the paper by Kilian (2009) connecting structural oil price shocks with the economy, Antonakakis et al. (2014) and Kang and Ratti (2013a, 2013b), among others, investigate the relationship between structural oil price shocks and economic policy uncertainty. They find that while oil price increases driven by real aggregate demand and oil-market specific demand shocks have long-term consequences for economic policy uncertainty, supply-side oil shocks do not greatly affect US economic policy uncertainty. ${ }^{2}$ The latter result is in line with findings in the literature that supply-side oil shocks are relatively unimportant compared to demand-side oil price shocks for the macro economy by Hamilton (2009), Kilian (2009), Lippi and Nobili (2012), and Baumeister and Peersman (2013b).

In this study, we investigate the influence of US and non-US oil supply shocks on US economic policy uncertainty. Theoretically, a US oil supply shock directly influences US income,

\footnotetext{
${ }^{1}$ A considerable literature has developed examining the connection between indices of economic policy uncertainty and stock markets in various countries: Mensi et al. (2014) for BRICS; Arouri and Roubaud (2016) for the US and China; Li et al. (2016) for China and India; Dakhlaoui and Aloui (2016) for BRIC over time; Gao and Zhang (2016) for the UK; Wu et al. (2016) for a panel of nine countries; and Chang et al. (2015) for seven OECD countries. The implications of economic policy uncertainty for sectoral returns has also been examined: Lean and Nguyen (2014) for sustainable investment returns in Asia Pacific and North America; Antonakakis et al. (2016) for U.S. sustainable investments; Balcilar et al. (2016) for gold returns and volatility; Kang et al. (2017) global oil and gas companies. Bekiros et al. (2016) argue for a non-linear forecasting connection between economic policy uncertainty stock market return volatility. Liu and Zhang (2015) find that economic policy uncertainty has forecasting power in volatility prediction models for the stock market.

${ }^{2}$ Literature examining the relationship between economic policy uncertainty and oil price shocks includes the following. Aloui et al. (2016) adopt a copula method to study the effect of economic policy uncertainty on crude-oil returns. Bekiros et al. (2015) find that economic policy uncertainty provides information useful in predicting the change in oil prices. Arouri et al. (2014) find that increased economic policy uncertainty in major net oil importers has a negative effect on Gulf Cooperation Council stock markets.
} 
whereas a non-US oil supply shock does not. This has implications for differential effects of US and non-US production shocks on economic policy uncertainty since the influence of oil shocks is thought to work through the demand for goods in the economy. Bernanke (2006) notes that energy prices affect aggregate activity primarily through effects on consumer spending and disposable income, an account supported by findings by Lee and Ni (2002) that oil price shocks influence activity at industry level through sector demand. ${ }^{3}$ Disaggregated oil supply variables may have different effects on US inflation and inflation expectations and forecasts about federal/state/local government expenditures, key components in economic policy uncertainty. Montoro (2012) and Natal (2012) argue that oil price shocks affect inflation and affect the monetary policy trade-off between inflation and output stabilization. Bernanke et al. (2004) argue that monetary policy influences the transmission of oil price shocks to the economy.

Our examination of the effects of the dis-aggregation of oil production shocks into US and non-US oil production shocks yield novel results. First, the recent literature attributes only moderate effect of supply shocks to economic policy uncertainty, while our results show relative large effect. ${ }^{4}$ Secondly, our results contribute to the literature of energy independency, supporting the view of Broadman and Hogan (1988), Anderson (1991) and Hall (1992), that an increase in energy independency has the potential to enhance not only economic growth but also has positive implications for economic policy and national security.

The investigation of the impacts of U.S. and non-U.S. oil supply shocks on U.S. economic policy uncertainty is particularly interesting given the unprecedented expansion in U.S.

\footnotetext{
${ }^{3}$ Oil shocks are connected with government activity and policy in a number of additional ways. Barro's (1979) taxsmoothing and Becker and Mulligan's (1997) inefficient-tax models predict an adjustment of taxes and government expenditure in response to wealth shocks. For oil exporting countries, El Anshasy and Bradley (2012) find that higher oil prices raises the size of government and for the US, Gelb (1988) finds that oil price shocks cause a rise in federal government purchases. Pieschacón (2012) shows that fiscal policy can affect the influence of oil price shocks on economic activity.

${ }^{4}$ Please see Antonakakis et al. (2014) and Kang and Ratti (2013a; 2013b).
} 
oil production since 2009. As observed in Figure 1, US oil production trended downward from the mid-1980s to 2009 and then experienced a rapid expansion due to innovations and new technologies in the extraction of crude oil. These developments in US oil production have wide ranging implications that may differ from those associated with non-US oil production. Dahl and Duggan (1996) conduct a survey and find that US oil supply elasticity appears to be elastic. Kaufman et al. (2009) find that shocks to oil prices ripple down the US oil supply chain and inventory behaviors. Hayat and Narayan (2011) report that shocks to US oil supply disruptions account for about 35 percent of the variation of the growth of crude oil and petroleum products ending stocks. Medlock III (2012) notes that the US has more oil exporting potential driven, in part, by the recent shale gas and tight oil boom. In a recent paper Kang et al. (2016) shows that the disaggregation of world oil supply into US and non-US oil supply is an important factor in determining US real stock returns. The authors find that a positive US oil supply shock has a positive impact on US real stock returns, in contrast to the established finding that shocks to global oil production are relatively unimportant in influencing real stock returns.

Non-US oil production shows a different pattern of behavior from that of the US oil production over 1985-2015. The major fluctuations of non-US oil production are associated with the 1990-1991 Gulf War, 2003 Iraq War, 2008-2009 Global Financial Crisis, 2011 Arab Spring, and the 2014-2015 oil price down. Figure 1 shows that in these periods, the major historical event outbreaks are followed by an increase in the economic policy uncertainty index. Shapiro and Watson (1988) also note that major oil price changes in 1970s and 1980s were driven by exogenous political events in the Middle East. Utilizing the geopolitical events as a proxy of exogenous oil supply disruption, Hamilton (2003) confirms the relation between oil price fluctuations and GDP growth. 
This study estimates a structural VAR model that recognizes the separate effects of US and non-US oil production shocks and of demand side influences on US economic policy uncertainty. Structural oil price shocks are found to explain $41 \%$ of the variation in economic policy uncertainty. Separation of oil production shocks into US and non-US oil production shocks is found to result in the conclusion that supply-side oil shocks are as important for economic policy uncertainty as are oil demand-side shocks, a modification of the view in the literature. At the 60 month forecast horizon over 1985 to 2015, US oil supply shocks and non-US oil supply shocks explain $20.7 \%$ of the variation in economic policy uncertainty and oil-market specific demand shocks and aggregate demand shocks explain $20.3 \%$ of the variation of economic policy uncertainty.

The response of economic policy uncertainty is positive and statistically significant to shocks to US oil supply disruption. Shocks to US oil supply disruption causes significant rises in the forecast interquartile ranges of the US CPI and accounts for $21 \%$ of the overall variation of the CPI forecaster disagreement. Innovations to US oil supply disruption are associated with $16 \%$ of the variation of the economic forecast interquartile ranges about federal/state/local government expenditures. It is also found that significantly increased US oil production for several months is associated with a positive shock to economic policy uncertainty.

The paper is organized as follows. Section 2 describes data sources and presents the structural VAR model. Section 3 discusses empirical results about the dynamics of oil price shocks and economic policy uncertainty. Section 4 concludes.

\section{Data and Methodology}

\subsection{Data}


We utilize monthly economic policy uncertainty and oil market data from January 1985 to December 2015. The oil supply proxy variables are given by the percent changes in non-US oil production ( $\Delta \operatorname{prod}_{t}^{\text {nonUs }}$ ) and in US oil production ( $\Delta \operatorname{prod}_{t}^{\text {US }}$ ) from the US Department of Energy. The global real economic activity proxy is the index of real economic activity (rea $a_{t}$ constructed by Kilian (2009). ${ }^{5}$ The real price of oil $\left(r p o_{t}\right)$ is US refiner acquisition cost of imported crude oil drawn from the US Department of Energy and deflated by the US CPI from the Bureau of Labor Statistics.

The policy-related economic uncertainty index $\left(p u_{t}\right)$ is developed by Baker et al. (2016). ${ }^{6}$ The index is a weighted average of four underlying uncertainty components: broad news-based policy uncertainty that quantifies the newspaper coverage of the policy-related economic uncertainty, tax legislation expiration uncertainty that reflects the number of federal tax code provisions set to expire in the future years, and the economic forecast interquartile ranges about US CPI and about federal/state/local government expenditures. Newspaper coverage reflects search results for articles containing terms related to economic policy uncertainty. The number of federal tax code provisions set to terminate measures the level of uncertainty regarding the course the federal tax code will take in the future. Forecaster disagreement over federal and state/local government purchases measures uncertainty about future fiscal policy. Forecast disagreement over future inflation is a representation of uncertainty about future monetary policy. Baker et al.’s (2016) economic uncertainty index gauges economic policy uncertainty about public views and economic policy making.

We conduct Augmented Dicky-Fuller (ADF), Phillips-Perron (PP) and KwiatkowskiPhillips-Schmidt-Shin (KPSS) tests for the stationarity of the oil and policy uncerainty

\footnotetext{
${ }^{5}$ The data are available at Kilian's webpage: http://www-personal.umich.edu/ lkilian/paperlinks.html.

${ }^{6}$ The data can be found at http://www.policyuncertainty.com/.
} 
variables. ${ }^{7}$ The test results in Panel A of Table 1 show that oil supply and demand variables contain a unit root at the $10 \%$ significant level, whereas the ADF and PP tests for the policy uncertainty reject the hypothesis containing a unit root at the $1 \%$ significant level. In this paper we utilize the global real economic activity index and the real price of crude oil in levels rather than the first-differences to preserve the low-frequency covariation in the oil market data. Given the impulse response functions are reasonably precisely estimated in the VAR model, the potential cost of level specification would only be reflected in wider error bands (see Sims et al. (1990) and Kilian and Murphy (2014)).

In Panels B, C, D and E of Table 1, we follow Hansen (1997, 2000) to present test results for the constancy of parameters in the oil-policy uncertainty dynamic VAR models. The asymptotic p-values of the Supremum (Sup), Exponential average (Exp) and Average (Ave) Langragian Multiplier tests fail to reject the parameter stability of the relation between an oil supply/demand variable and the economic policy uncertainty. The set of tests is for structural change of unkown timing in the regression models. To further assess the extent and nature of parameter instability issues of the forecasting, a rolling sample analysis is followed in Section

\section{5.}

\subsection{Methodology}

This study considers a structural VAR model of order $p$ to extract the separate supply and demand-side sources underlying oil price changes and their relation to the policy-related economic uncertainty in the following:

\footnotetext{
${ }^{7}$ In the literature, the traditional tests for the stationarity include the work by Dickey and Fuller (1979), Elliot et al. (1996), Kwiatkowski et al. (1992), Ng and Perron (2001), Phillips and Perron (1988). The Phillips-Perron test has the same power properties as the ADF test. Because both tests lack power it is possible that the failure to reject the null in one case is simply a type II error. Employing two tests with the same power and size properties will not enhance the properties of either and it could be argued that the ADF Generalised Least Squares test might be more powerful. However, failure to reject the null in this one variable is not decisive for the model. Other tests such as ERS, KPSS and NP are then suggested in the investigation.
} 


$$
A_{0} y_{t}=c_{0}+\sum_{i=1}^{p} A_{i} y_{t-i}+\varepsilon_{t} \text {, }
$$

where $y_{t}=\left(\Delta \operatorname{prod}_{t}^{\text {nonUs }}, \Delta \operatorname{prod}_{t}^{\text {US }}, \operatorname{rea}_{t}, r p o_{t}, p u_{t}\right)$ is a $5 \times 1$ vector of endogenous variables, $A_{0}$ denotes the $5 \times 5$ contemporaneous coefficient matrix, $c_{0}$ represents a $5 \times 1$ vector of constant terms, $A_{i}$ refers to the $5 \times 5$ autoregressive coefficient matrices, and $\varepsilon_{t}$ stands for a $5 \times 1$ vector of serially and mutually uncorrelated structural disturbances.

We follow the setup in Kilian (2009) to assume that $A_{0}^{-1}$ has a recursive structure such that the reduced-form VAR error term $e_{t}$ can be decomposed by $e_{t}=A_{0}^{-1} \varepsilon_{t}$. The identifying restrictions on $A_{0}^{-1}$ postulate a lower-triangle coefficient matrix in the structural VAR model. Kilian (2009) argues that oil production does not respond to contemporaneous changes in oil demand within a given month because of the high adjustment cost of changing oil production. Fluctuation in the real price of oil will not affect global economic activity within a given month due to the sluggishness of aggregate economic reaction. The US economic policy uncertainty ordered after oil price shocks is motivated by Lee and Ni (2002), Kilian and Park (2009), and Kilian and Vega (2011), who argue that oil prices are predetermined with respect to U.S. macroeconomic aggregates within a given month. While US economic policy uncertainty is allowed however to respond to oil supply and demand shocks on impact, shocks to the policy uncertainty are assumed to affect the global oil market only with a delay of at least one month. Kang et al. (2016) argue that non-US oil production does not respond to US oil supply shock within a given month. The US has been an oil importing country whose oil production averages about $11.3 \%$ of the global oil production over January 1985 to December 2015. We assume that 
shocks to the US oil supply affect the non-US oil production only with a delay of at least one month.

\section{Empirical Result}

\subsection{Responses to One-Standard Deviation Structural Shocks}

In this subsection we present the responses of all endogenous variables in Equation (1) to one-standard deviation structural innovations. We utilize the estimates of the reduced-form VAR model that is consistently estimated by the least-squares method to construct the structural VAR representation of the model. Figure 2 shows the point estimates of the impulse response functions in the forecasting horizon 24 months to a structural shock together with one- and twostandard error bands constructed using a recursive-design wild bootstrap with 2,000 replications.

The impulse responses of US economic policy uncertainty to one-standard deviation structural shock are presented in the last row in Figure 2. An unexpected non-US oil supply disruption on economic policy uncertainty are mostly negative and statistically insignificant, although there is a statistically significantly negative effect on the economic policy uncertainty at the $11^{\text {th }}$ month. In contrast, the responses of the policy uncertainty to an unexpected US oil supply disruption are positive in general and statistically significant in five of the first six months. The implication is that a positive innovation in US oil supply significantly reduces economic policy uncertainty, whereas a positive innovation in non-US oil supply qualitative does not. An unanticipated real aggregate demand shock causes a statistically significantly negative effect on the policy uncertainty in the window between the $3^{\text {rd }}$ and the $7^{\text {th }}$ month. The responses of the policy uncertainty to an oil-market specific demand shock, however, are marginally statistically significantly positive in the $5^{\text {th }}$ month and in the window between the $9^{\text {th }}$ and the $17^{\text {th }}$ month. 
The first column of Figure 2 illustrates the responses of an endogenous variable to nonUS oil supply shocks. An unexpected non-US oil supply shock causes a sharp decline in the nonUS oil production upon impact. The declined effect exhibits a partial reversal within the first year and shows persistence afterwards. This shock causes a cumulative rise in the US oil production from the $1^{\text {st }}$ to the $24^{\text {th }}$ month. The results are consistent with the view by Kilian (2009) that oil supply contractions in non-US region tend to trigger production in US. In contrast, the first diagram of the second column of Figure 2 shows that unexpected US oil supply shocks have a statistically nonsignificant effect on the non-US oil production. It provides supporting evidence on the identifying restrictions based on Kang et al. (2016) who argue that non-US oil production does not respond to US oil supply shock within a given month. The intuition is that the non-US oil production on average is about eight times of the US oil production over January 1985 to December 2015. It requires a large decline in the US oil supply for the non-US oil production reaction.

The third column of Figure 2 shows that an unanticipated real aggregate economic expansion causes positive effects on the non-US oil production, whereas this shock has statistically significantly negative effects on the US oil production at the $11^{\text {th }}$ month. The fourth column of Figure 2 shows that an unexpected oil-market specific demand shock causes statistically significant negative effects on the non-US oil production after the $18^{\text {th }}$ month. In contrast, this shock causes statistically significantly positive effects on the US oil production after the $15^{\text {th }}$ month. The US economic policy shock does not show significant effect on the nonUS oil production, whereas this shock causes a statistically significantly positive effect on the US oil production upon impact, then exhibiting a reversal of that rise within the first three months. In the fifth column, US oil production responds positively to a positive shock to 
economic policy uncertainty and the effect is statistically significant for the first four months. Non-US oil production does not respond significantly to shocks to US economic policy uncertainty.

In summary, the response of US economic policy uncertainty is different to dissimilar oil supply and demand shocks. The response of economic policy uncertainty is negative to the

shocks of non-US oil supply disruption and aggregate demand expansion, and is statistically significantly and positive to the shocks of US oil supply disruption and oil-market specific demand. The response of US oil production is different from that of non-US oil production to the structural oil price shocks. The responses of US oil production are statistically significantly positive to non-US oil supply disruption, negative to real aggregate demand shock, positive to oil-market specific demand innovation, and positive to the economic policy uncertainty shock. The responses of non-US oil production, however, are statistically significantly positive to real aggregate demand shock and negative to oil-market specific demand innovation. These results confirm that in analyzing the influence of oil prices on the policy uncertainty it is essential to identify the underlying source of the oil price shocks.

\subsection{Historical Decomposition of Economic Policy Uncertainty to the Structural Shock}

The historical decomposition of the effect of the structural oil price shocks reported in Figure 3 provides us with the information on how the structural shocks have contributed to the economic policy uncertainty over time. The first panel shows that the historical effect of non-US oil supply shocks on the US economic policy uncertainty is comparatively small. US oil supply shocks in the second panel, however, cause a long swing in the economic policy uncertainty over 1990 - 2010. The cumulative contributions of real aggregate demand and oil-market specific demand shocks to the policy uncertainty are relatively large. While shocks to global aggregate 
demand cause a long swing in the policy uncertainty over 1990 - 2015, innovations in the oilmarket specific demand are responsible for fairly sharply defined increases and decreases in the US economic policy uncertainty in the 1990 - 1991 Gulf War, before the 2003 Iraq War, and during the 2008-2009 Global Financial Crisis in particular. The historical decomposition of fluctuations in the US economic policy uncertainty indicates that the policy uncertainty shocks historically have been driven mainly by a combination of US oil supply shocks and oil demand side shocks, instead of the non-US oil supply shocks.

\subsection{Variance Decomposition of the US Economic Policy Uncertainty}

The variance decomposition in Panel A of Table 2 quantifies how important the structural shocks have been on average for the US economic policy uncertainty. In the first few months the effects of the structural shocks in the crude oil market on the policy uncertainty are negligible. Over time the explanatory power of the structural oil price shocks increases. After 60 months $41 \%$ of the variation in the US economic policy uncertainty is accounted for by the innovations of the supply and demand oil shocks. The contributions of US oil supply shocks and oil-market specific demand shocks explain $12.9 \%$ and $12.3 \%$ of the overall variation of the policy uncertainty, respectively. When oil supply shocks are differentiated by US and non-US origins, shocks on the supply side of the oil market explain as much of the variation in economic policy uncertainty as do structural shocks on the demand side of the oil market.

Panel B of Table 2 presents a summary of the variance decomposition of all the structural shocks at the forecast horizon 60 months. The table shows that the spillover between the crude oil market and the US economic policy uncertainty is comparatively large. The spillover index is 0.389 and is highly statistically significant with a t-value 10.72 .

\subsection{The Transmission Channel of Oil Price Shocks to the US Policy Uncertainty}


The index of economic policy uncertainty is a weighted average of four underlying components: 1/2 weight for broad news-based policy uncertainty, and 1/6 weight each for government purchase forecast interquartile range, CPI forecaster disagreement, and the tax code expiration uncertainty respectively. We utilize the four uncertainty components to investigate the transmission channel of how oil supply and demand side shocks affect US policy-related economic uncertainty. The analysis is conducted by estimating four analogous structural VAR models with each component ordered last instead of the overall economic policy uncertainty in Equation (1).

Figure 4 reports the point estimates of the impulse response functions of the components of economic policy uncertainty over 24 months forecasting horizon of structural shock with oneand two-standard error bands (constructed using a recursive-design wild bootstrap with 2,000 replications). We will focus on the impacts of negative innovations in US oil production reported in the second column of Figure 4. An unexpected shock to US oil supply disruption causes a statistically significant positive impact on news-based policy uncertainty in the first 2 months. This effect then dissipates over time. An innovation to US oil supply disruption raises the forecast interquartile ranges about federal/state/local government expenditures with significant effects over the $10^{\text {th }}$ through $14^{\text {th }}$ months. An unexpected shock to US oil supply disruption causes rises in the forecast interquartile ranges for the CPI (CPI forecaster disagreement), with statistically significant results out over 4 to 7 months and out over 13 to 16 months. Effects of innovation to US oil supply interruption on the number of federal tax code provisions set to expire are negative and are not statistically significant.

The contributions of structural shocks to variation in the components of economic policy uncertainty are reported in Table 3. The last column in Table 3 implies that the structural oil 
price shocks collectively explain $35 \%, 53 \%, 49 \%$ and $42 \%$ of the variation in news-based, expenditure dispersion, CPI disagreement and tax expiration uncertainties after 60 months, respectively. These numbers contrast with the $41 \%$ of the variation in economic policy uncertainty overall explained by structural oil price shocks (from Table 2).

In Table 3, shocks to US oil supply account for $21 \%$ and of the variation of the CPI forecaster disagreement at the 60-month horizon. In contrast, shocks to non-US oil supply contribute only $1.6 \%$ to the explanation for variation in the CPI forecaster disagreement. Innovations to US oil supply are associated with $16 \%$ and of the variation of expenditure dispersion uncertainty at the 60-month horizon. Shocks to US oil supply explain $6.2 \%$ and $6.4 \%$ of variations in news-based and tax expiration uncertainties. Shocks to US oil production affect economic policy uncertainty mainly through impacts on the economic forecast interquartile ranges about US CPI and about federal/state/local government expenditures.

\subsection{Rolling Sample Analysis}

In this subsection, we examine the time-varying effects of the structural oil supply and demand shocks on the US policy-related economy uncertainty. Hamilton (2013) argues that the global oil market has a major change since the early 1970s. Baumeister and Peersman (2013a, 2013b) show that the volatility of global oil production has trended downwards over the last thirty-five years. As observed in Figure 1, the study is particularly motivated by the period after 2009 in that period US oil production experiences an unprecedented expansion due to innovations and new technologies in the extraction of crude oil. We estimate the structural VAR model using 193-month rolling samples in order to assess the extent and nature of spillover variation starting in January 2001. The rolling sample analysis uses the first sample over 
1985:01-200:12, the second sample over 1985:02-2001:01, etc., with each subsequent sample adding one new month and dropping the first month of the data in the preceding sample.

We present the spillover index introduced by Diebold and Yilmaz (2009; 2014) in Figure 5, showing a summary of the contributions of shocks to a variable to the forecast error variances of that variable and other endogenous variables in the VAR model. The result in Figure 5 is in line with the finding by Antonakakis et al. (2014) that the spillovers increase considerably during the Global Financial Crisis of 2008 - 2009. Spillovers of oil prices and policy uncertainty in the period of 2006-2007 increase dramatically following the Hurricane Katrina in 2005 and there are substantial upticks in the spillover index at the time of the Arab Spring in 2011. Spillovers between oil market shocks and economic policy uncertainty fell during 2012 and 2013 and remained in a lower range over 2014 and 2015 level as the oil price turns down.

The dynamic contributions of the individual structural oil shocks to economic policy uncertainty are shown in Figure 6. In July 2008 the dynamic contribution of shocks to US oil production in the long run reaches the peak height of $36 \%$ of the overall variation in US policyrelated economy uncertainty. This contribution of shocks to US oil production economic policy uncertainty displays a decreasing trend after 2010.

The dynamic contribution of non-US oil production shocks to the overall variation of economic policy uncertainty in Figure 6 rises in association with major global oil supply disruptions due to the 1990-1991 Gulf War, 2003 Iraq War, 2008-2009 Global Financial Crisis, and 2011 Arab Spring. Following a long rise of real activity over 2001-2004 and a significant drop of the real activity over 2005-2006, the dynamic contribution of shocks to aggregate demand reaches its highest point in 2005:10. During the 2008-2009 Global Financial Crisis and 2011 Arab Spring, the contribution of oil-market specific demand shocks is sharply increased in 
the overall variation of economic policy uncertainty. These results confirm that Oil price shocks and economic policy uncertainty are interrelated. The direct effects of oil shocks on the real activity are amplified by endogenous policy uncertainty responses.

\subsection{Asymmetric response of policy uncertainty to oil price shocks}

This subsection investigates the effect of oil shocks on the degree of asymmetry in the response of economic policy uncertainty to the oil price increases and decreases. The asymmetric responses of real activity to changes in crude oil prices have been heavily studied in the literature (e.g., Radchenko (2005) for real gasoline prices, Huang et al. (2006) for changes in industrial production and real stock returns, and Kilian and Vigfusson (2011) for unemployment, gasoline consumption and real GDP).

We follow Kilian and Vigfusson (2011) and consider a simple bivariate VAR model for the test of the asymmetric responses:

$$
\begin{aligned}
o_{t} & =a_{10}+\sum_{i=1}^{p} a_{11, i} o_{t-i}+\sum_{i=1}^{p} a_{12, i} p u_{t-i}+\varepsilon_{1, t}, \\
p u_{t} & =a_{20}+\sum_{i=0}^{p} a_{21, i} o_{t-i}+\sum_{i=1}^{p} a_{22, i} p u_{t-i}+\sum_{i=0}^{p} g_{21, i} o_{t-i}^{+}+\varepsilon_{2, t} .
\end{aligned}
$$

In the nonlinear VAR model (2), $p u_{t}$ denotes the economic policy uncertainty, $o_{t}$ represents the growth rate of non-US oil production, US oil production, real price of oil, or the real aggregate demand, and $o_{t}^{+}=\max \left(o_{t}, 0\right)$ is defined as the increase of $o_{t}$. The dynamic responses to unanticipated positive and negative oil price changes are calculated based on the estimates of the regression coefficients.

Figure 7 shows asymmetric responses $I_{p u}(h, \sigma)$ and $-I_{p u}(h,-\sigma)$ of the economic policy uncertainty to one standard deviation oil price shocks. For example, for oil production changes, the response $I_{p u}(h, \sigma)$ is to an increase in oil production and $-I_{p u}(h,-\sigma)$ is the negative of the response to a decrease in oil production. The difference between the two responses is relatively 
larger to non-US oil supply shocks than that to other shocks. The corresponding tests of the symmetry, reported in Panel 1 of Table 4 based on 20,000 simulation of model (2), also present a higher statistically significant level of the asymmetric responses to the non-US oil supply shocks. On reading Table 4, in Panel 4, the null hypothesis of symmetry of CPI dispersion response to positive and negative US oil supply changes cannot rejected at 0,1 and 3 months (p values of $0.175,0.394,0.452)$, but is rejected at $5 \%$ level at 6 month horizon and at $1 \%$ level for 12 and 24 month horizons.

Figure 8 illustrates the asymmetric responses of policy uncertainty components to one standard deviation oil supply shocks. The responses of policy uncertainty components are relatively stronger to the decrease in oil production than that to the increase in oil production in general. The difference between the negative and positive responses of expenditure dispersion is relatively larger in the fourth diagram of Figure 8 and highly statistically significant in the third column of Panel 3 in Table 4 to the US oil supply shocks. The difference between the negative and positive responses of taxation expiration uncertainty is relatively larger but statistically nonsignificant within a year to the non-US oil supply shocks. For the policy uncertainty components, the symmetric responses of News, Expenditure and Taxation (CPI) uncertainty are more likely to be rejected for shocks to positive and negative to US (non-US) oil supply shocks.

Finally, we change the order of the first variable non-US oil production and the second variable US oil production in the structural VAR model. The results (not report here) show that the fraction of forecast error variance decomposition of policy uncertainty and the pattern of its responses upon four oil price shocks is very similar to that reported in Table 2 and Figure 2.

\section{Conclusion}


This study utilizes a structural VAR model to estimate the effects of US and non-US oil production shocks and of demand side influences on US economic policy uncertainty. After 60 months, structural oil price shocks explain $41 \%$ of the variation in economic policy uncertainty overall, and $53 \%$ and $49 \%$ of the variation in expenditure dispersion and CPI disagreement uncertainties, respectively. Oil supply shocks identified by US and non-US origins explain as much of the variation in economic policy uncertainty as structural shocks on the demand side of the oil market. At the 60 month forecast horizon over 1985 to 2015, US oil supply shocks (oilmarket specific demand shocks) explain $12.9 \%$ (12.3\%) of the variation of the economic policy uncertainty, and non-US oil supply shocks (aggregate demand shocks) explain 7.8\% (8.0\%) of the variation of economic policy uncertainty. The separation of oil production shocks into US and non-US oil production shocks modifies the view in much of the literature that supply-side oil shocks have little consequence for economic policy uncertainty.

We find that economic policy uncertainty responds differently to US oil production shocks and non-US oil production shocks. The response of economic policy uncertainty is positive and statistically significant to shocks to US oil supply disruption and negative and not statistically significant to shocks to non-US oil supply disruption. The economic forecast interquartile ranges about the US CPI and about federal/state/local government expenditures are particularly sensitive to innovations in US oil supply shocks. Shocks to US oil supply disruption causes significant rises in the CPI forecast uncertainty and accounts for $21 \%$ of the overall variation of the CPI forecaster disagreement. Innovations to US oil supply disruption are associated with $16 \%$ of the variation of expenditure dispersion uncertainty at the 60 -month horizon. 
The finding in this paper suggests that enhance domestic oil production in the US has consequences for political and economic security since positive shocks to US oil production are associated with lower US economic policy uncertainty. In addition, significantly increased US oil production for several months is associated with a shock to increased economic policy uncertainty. Shocks to US oil production affect economic policy uncertainty mainly through impacts on the economic forecast interquartile ranges about US CPI and about federal/state/local government expenditures. The results suggest that in analyzing the influence of structural oil market shocks on economic policy uncertainty it is important to differentiate between oil supply shocks originating inside and outside of the US. 


\section{References}

Anderson, I., 1991. “Black Gold” obscures green vision in US, New scientist 129, 14.

Andrews, D.W.K., 1993. Tests for parameter instability and structural change with unknown change point. Econometrica 61, 821-856.

Andrews, D.W.K., Ploberger, W., 1994. Optimal tests when a nuisance parameter is present only under the alternative. Econometrica 62, 1383-1414.

Antonakakis, N., Babalos, V., Kyei, C., 2016. Predictability of sustainable investments and the role of uncertainty: evidence from a non-parametric causality-in-quantiles test. Applied Economics 48, 4655-4665.

Antonakakis, N., Chatziantoniou, I., Filis, G., 2014. Dynamic spillovers of oil price shocks and economic policy uncertainty. Energy Economics 44, 433-447.

Aloui, R., Gupta, R., Miller, S.M., 2016. Uncertainty and crude oil returns. Energy Economics 55, 92-100.

Arouri, M., Roubaud, D., 2016. On the determinants of stock market dynamics in emerging countries: The role of economic policy uncertainty in China and India. Economics Bulletin 36 (2), 760-770.

Arouri, M., Rault, C., Teulon, F., 2014. Economic policy uncertainty, oil price shocks and GCC stock markets. Economics Bulletin 34, 1822-1834.

Baker, S.R., Bloom, N., Davis, S.J., 2016. Measuring economic policy uncertainty. Quarterly Journal of Economics 131, 1593-1636.

Balcilar, M., Gupta, R., Pierdzioch, C., 2016. Does uncertainty move the gold price? New evidence from a nonparametric causality-in-quantiles test. Resources Policy 49, 74-80.

Barro, R., 1979. On the determination of the public debt. Journal of Political Economy 87, 940971.

Bata, E., Izzeldin, M., Osborn, D.R., 2016. Changes in the global oil market. Energy Economics 56, 161-176.

Baumeister, C., Peersman, G., 2013a. The role of time-varying price elasticities in accounting for volatility changes in the crude oil market. Journal of Applied Econometrics 28, 1087-1109.

Baumeister, C., Peersman, G., 2013b. Time-varying effects of oil supply shocks on the U.S. economy. American Economic Journal: Macroeconomics 5, 1-28. 
Becker, G.S., Mulligan, C.B., 1997. Efficient taxes, efficient spending, and big government. University of Chicago, mimeo.

Bekiros, S., Gupta, R., Paccagnini, A., 2015. Oil price forecastability and economic uncertainty. Economics Letters 132, 125-128.

Bekiros, S., Gupta, R., Kyei, C., 2016. On economic uncertainty, stock market predictability and nonlinear spillover effects. North American Journal of Economics and Finance 36, 184-191.

Bernanke, B.S., 2006. Energy and the Economy. Economic Club of Chicago. Speech on June 15.

Bernanke, B.S., Gertler, M., Watson, M.W., 2004. Oil shocks and aggregate macroeconomic behavior: The role of monetary policy: reply. Journal of Money, Credit and Banking 36, 287-291.

Bloom, N., 2009. The impact of uncertainty shocks. Econometrica 77, 623-685.

Broadman, H.G., Hogan, W.W., 1988, Is an oil tariff justify? An American debate: the numbers say yes. The Energy Journal 9, 31-59.

Chang, T., Chen, W.-Y., Gupta, R., Nguyen, D.K., 2015. Are stock prices related to the political uncertainty index in OECD countries? Evidence from the bootstrap panel causality test. Economic Systems 39, 288-300.

Dahl, C., Duggan, T.E., 1996. US energy product supply elasticities: A survey and application to the US oil market. Resource and Energy Economics 18, 243-263.

Dakhlaoui, I., Aloui, C., 2016. The interactive relationship between the U.S. economic policy uncertainty and BRIC stock markets. International Economics 146, 141-157.

Diebold, F.X., Yilmaz, K., 2009. Measuring financial asset return and volatility spillovers, with application to global equity markets. Economic Journal 119, 158-171.

Diebold, F.X., Yilmaz, K., 2014. On the network topology of variance decompositions: Measuring the connectedness of financial firms. Journal of Econometrics 182, 119-134.

Dickey, D.A, Fuller, W.A., 1979. Distribution of the Estimators for Autoregressive Time Series with a Unit Root. Journal of the American Statistical Association 74, 427-431.

El Anshasy, A.A., Bradley, M.D., 2012. Oil prices and the fiscal policy response in oil-exporting countries. Journal of Policy Modeling 34, 605-620.

Elliot, G., Rothenberg, T.J., Stock, J.H., 1996. Efficient Tests for an Autoregressive Unit Root. Econometrica 64, 813-836.

Gao, R., Zhang, B., 2016. How does economic policy uncertainty drive gold-stock correlations? Evidence from the UK. Applied Economics 48 (33), 3081-3087. 
Gelb, A.H., 1988. Oil windfalls: Blessing or curse? Oxford University Press for the World Bank.

Hall, D.C., 1992.Oil and national security. Energy Policy 20, 1089-1096.

Hamilton, J.D., 2003. What is an Oil Shock? Journal of Econometrics 113, 363-398.

Hamilton, J.D., 2009. Causes and consequences of the oil shock of 2007-08. Brookings Papers on Economic Activity, Spring, 215-261.

Hamilton, J.D., 2013. Historical oil shocks. In: Parker, R.E., Whaples, R.M. (Eds.), The Routledge Handbook of Major Events in Economic History. Routledge Taylor and Francis Group, New York, 239-265.

Hansen, B.E., 1997. Approximate asymptotic p values for structural-change tests. Journal of Business \& Economic Statistics 15, 60-67.

Hansen, B.E., 2000. Testing for structural change in conditional models. Journal of Econometrics 97, 93-115.

Hayat, A., Narayan, P.K., 2011. Do demand and supply shocks explain USA's oil stock fluctuations. Applied Energy 88, 2908-2915.

Huang, B.N., Hwang, M.J. and Peng, H.P., 2005. The asymmetry of the impact of oil price shocks on economic activities: an application of the multivariate threshold model. Energy Economics 27, 455-476.

Kang, W., Perez de Gracia, F., Ratti, R.A., 2017, Oil price shocks, policy uncertainty, and stock returns of oil and gas corporations. Journal of International Money and Finance 70, 344-359.

Kang, W., Ratti, R.A., 2013a. Structural oil price shocks and policy uncertainty. Economic Modelling 35, 314-319.

Kang, W., Ratti, R.A., 2013b. Oil shocks, policy uncertainty and stock market return. Journal of International Financial Markets, Institutions and Money 26, 305-318.

Kang, W., Ratti, R.A., Vespignani, J., 2016. The impact of oil price shocks on the U.S. stock market: A note on the roles of U.S. and non-U.S. oil production. Economics Letters 145, 176181.

Kaufmann, R.K., Dees, S., Mann, M., 2009. Horizontal and vertical transmissions in the US oil supply chain. Energy Policy 37, 644-650.

Kilian, L., 2009. Not all oil price shocks are alike: disentangling demand and supply shocks in the crude oil market. American Economic Review 99, 1053-1069. 
Kilian, L., Murphy, D.P., 2014. The role of inventories and speculative trading in the global market for crude oil. Journal of Applied Econometrics 29, 454-478.

Kilian, L., Vigfusson, R.J., 2011. Are the responses of the US economy asymmetric in energy price increases and decreases? Quantitative Economics 2, 419-453.

Kilian, L., Vega, C., 2011. Do energy prices respond to U.S. macroeconomic news? A test of the hypothesis of predetermined energy prices. Review of Economics and Statistics 93, 660-671.

Kwiatkowski D., Phillips, P.C.D., Schmidt, P., Shin, Y., 1992. Testing the null hypothesis of stationarity against the alternative of a unit root: How sure are we that economic time series have a unit root? Journal of Econometrics 54, 159-178.

Lean, H.H., Nguyen, D.K., 2014. Policy uncertainty and performance characteristics of sustainable investments across regions around the global financial crisis. Applied Financial Economics 24, 1367-1373.

Lee, K., Ni, S., 2002. On the dynamic effects of oil price shocks: A study using industry level data. Journal of Monetary Economics 49, 823-852.

Li, X.-L., Balcilar, M., Gupta, R. , Chang, T., 2016. The Causal Relationship between Economic Policy Uncertainty and Stock Returns in China and India: Evidence from a Bootstrap Rolling Window Approach. Emerging Markets Finance and Trade 52 (3), 674-689.

Lippi, F., Nobili, A., 2012. Oil and the macroeconomy: a quantitative structural analysis. Journal of the European Economic Association 10 (5), 1059-1083.

Liu, L., Zhang, T., 2015. Economic policy uncertainty and stock market volatility. Finance Research Letters 15, 99-105.

Medlock III, K.B., 2012. Modeling the Implications of Expanded US Shale Gas Production. Energy Strategy Reviews 1, 33-41.

Mensi, W., Hammoudeh, S., Reboredo, J.C., Nguyen, D.K., 2014. Do global factors impact BRICS stock markets? A quantile regression approach. Emerging Markets Review 19, 1-17.

Montoro, C., 2012. Oil shocks and optimal monetary policy. Macroeconomic Dynamics 16, 240277.

Natal, J.-M., 2012. Monetary policy responses to oil price shocks. Journal of Money, Credit and Banking 44, 53-101.

Ng, S. and Perron, P., 2001. Lag Length Selection and the Construction of Unit Root Tests with Good Size and Power. Econometrica 69, 519-1554. 
Pieschacón, A., 2012. The value of fiscal discipline for oil-exporting countries. Journal of Monetary Economics 59, 250-268.

Phillips, C.B.P, Perron, P., 1988. Testing for a unit root in time series regression. Biometrika 75 (2), 335-346.

Radchenko, S., 2005. Oil price volatility and the asymmetric response of gasoline prices to oil price increases and decreases. Energy economics 27, 708-730.

Shapiro, M., Watson, M., 1988. Sources of business cycle fluctuations. NBER Macroeconomics Annual, 111-148.

Sims, C.A., Stock, J.H., Watson, M.W., 1990. Inference in linear time series models with some unit roots. Econometrica 58, 113-144.

Wu, T.-P., Liu, S.-B., Hsueh, S.-J., 2016. The Causal Relationship between Economic Policy Uncertainty and Stock Market: A Panel Data Analysis. International Economic Journal 30, 109122. 
Figure 1. US and Non-US oil production, economic policy uncertainty, 1985:01 - 2015:12

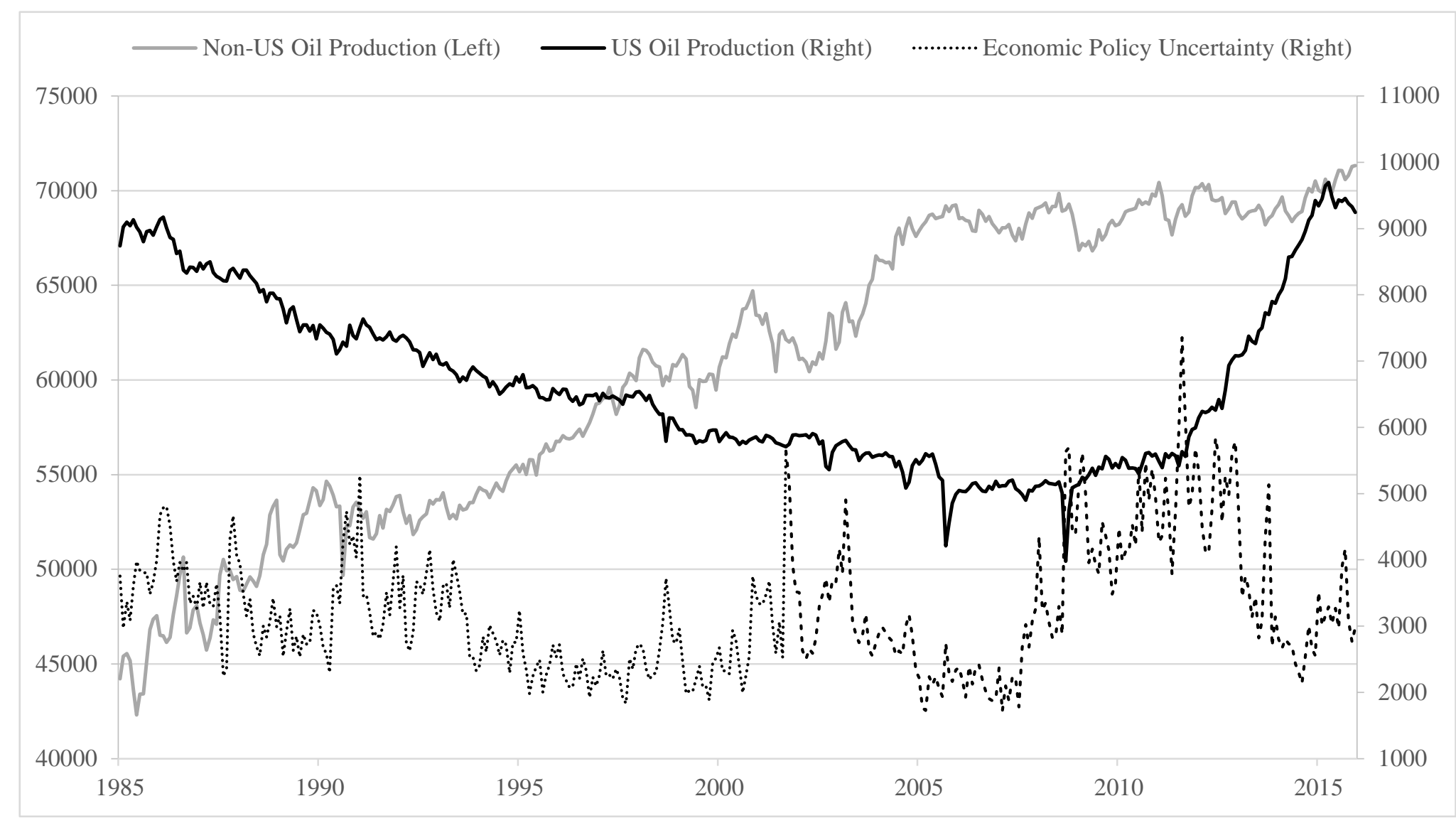

Notes: the figure shows monthly data of world Non-US oil production, US oil production, and economic policy uncertainty index between 1985:01-2015:12. The economic policy uncertainty index is multiplied by 30 for the exposition purpose. 


\section{Figure 2. Responses to one-standard deviation structural shock}
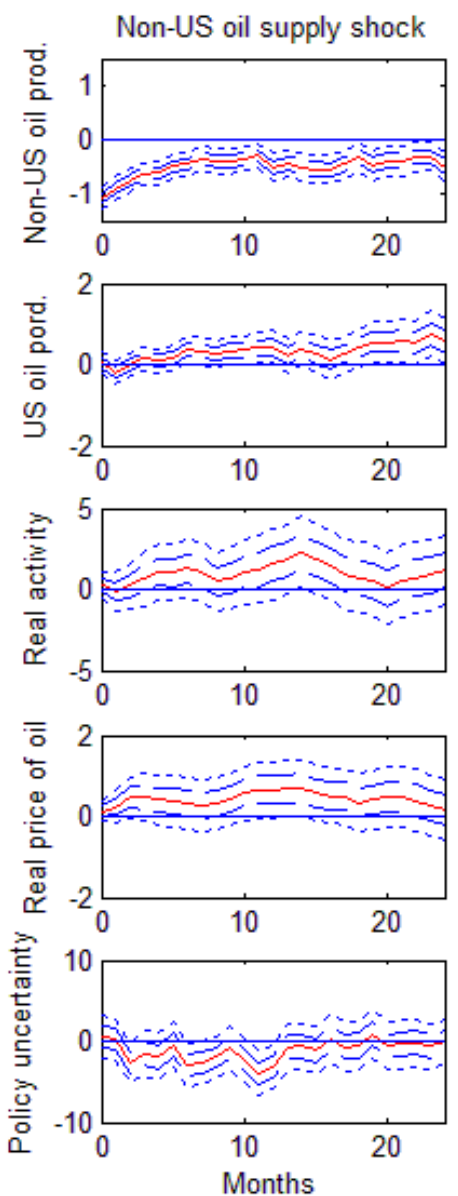
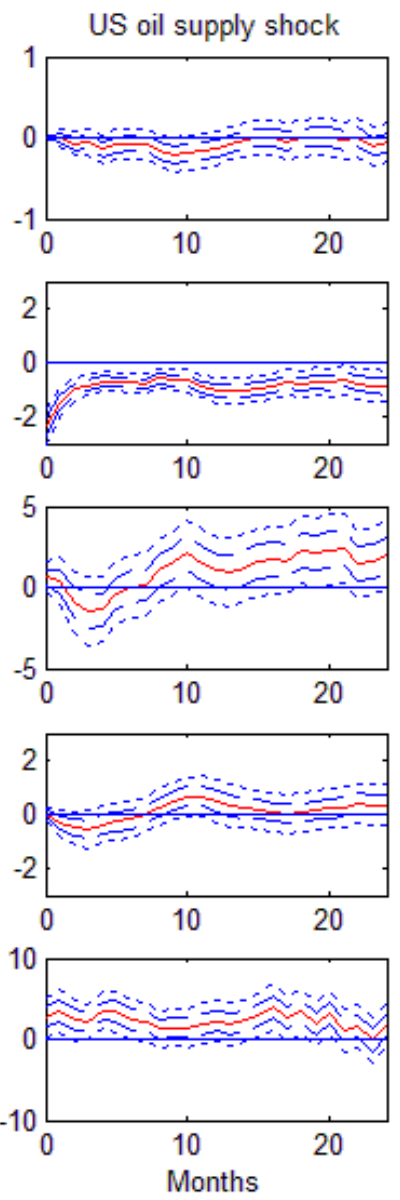
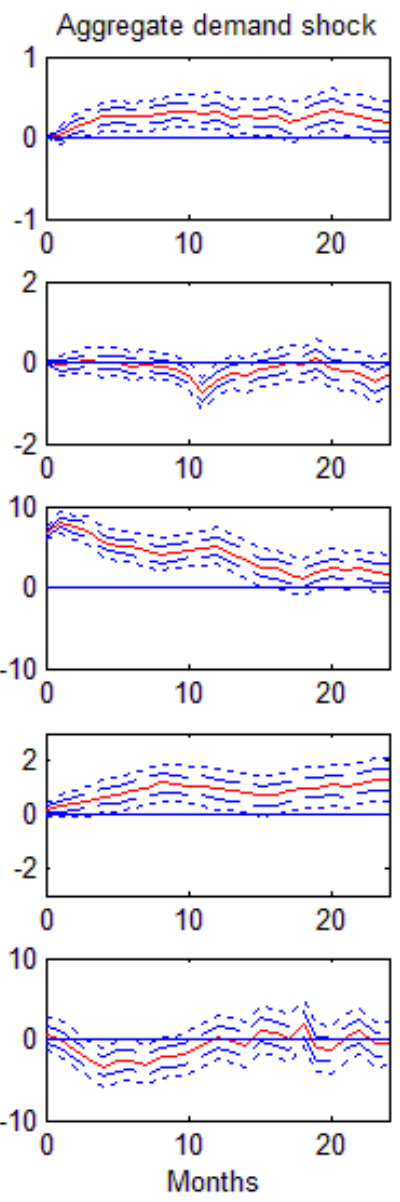
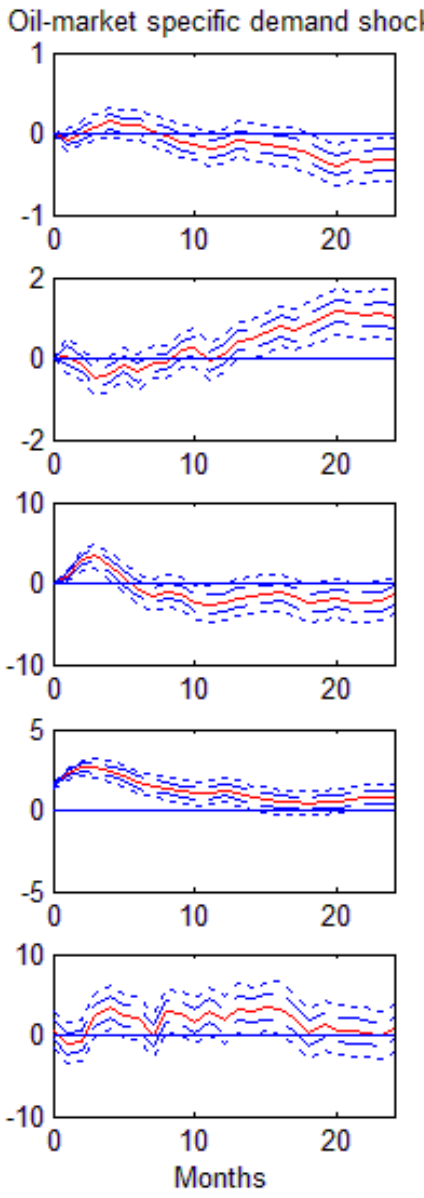

Policy uncertainty shock
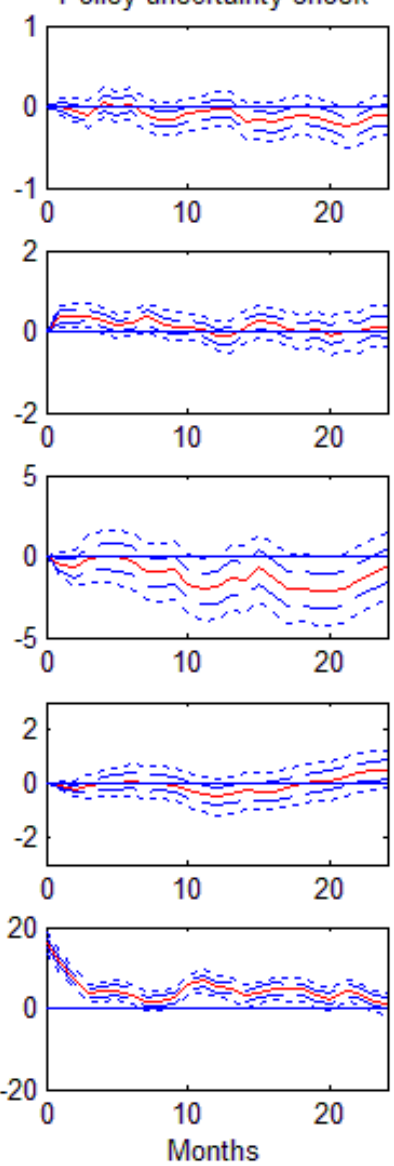

Notes: Point estimates, with one- and two-standard error bands, derived from the structural VAR model described in the text. The confidence intervals were constructed using a recursive-design wild bootstrap. The impulse responses of a variable indicated on the left hand side to shocks indicated along the top of the figure appear in each row. Thus, for example, the impulse responses of US economic policy uncertainty to one-standard deviation structural shock are presented in the last row in Figure 2. 


\section{Figure 3. Historical decomposition of economic policy uncertainty}
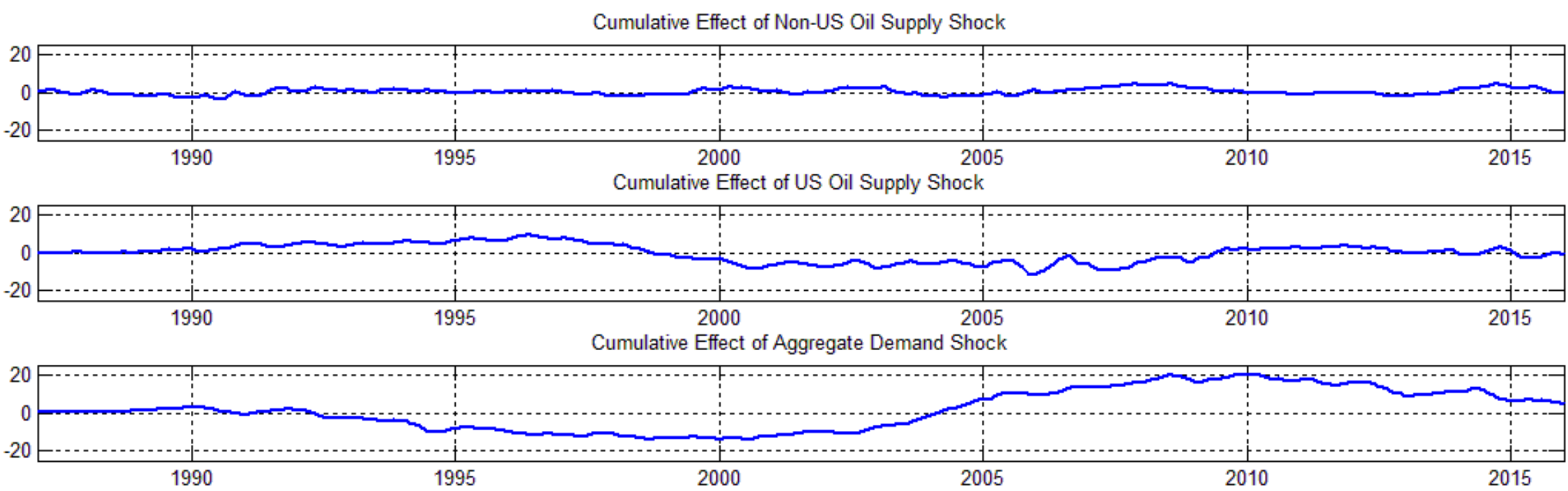

Cumulative Effect of Oil-Market Specific Demand Shock

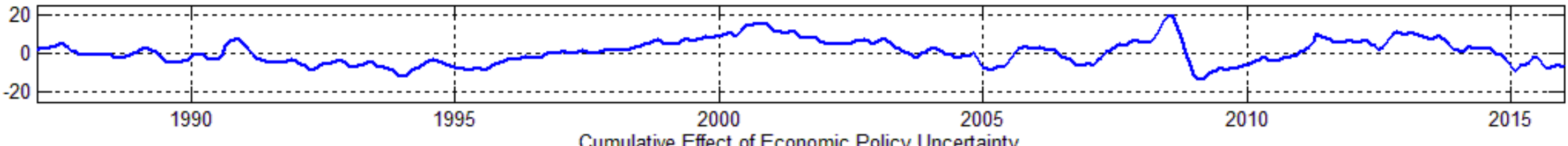

Cumulative Effect of Economic Policy Uncertainty

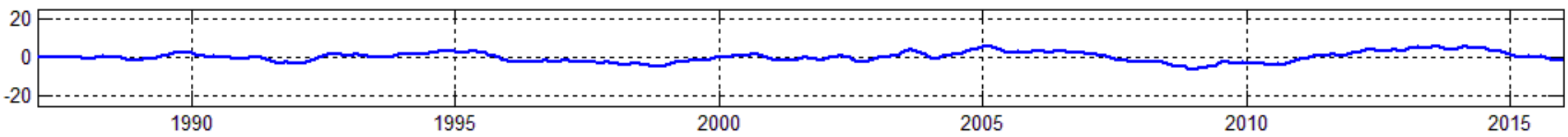

Notes: Estimates derived from the structural VAR model described in the text, averaged to annual frequency. 
Figure 4. Responses of economic policy uncertainty components to one-standard deviation structural shock
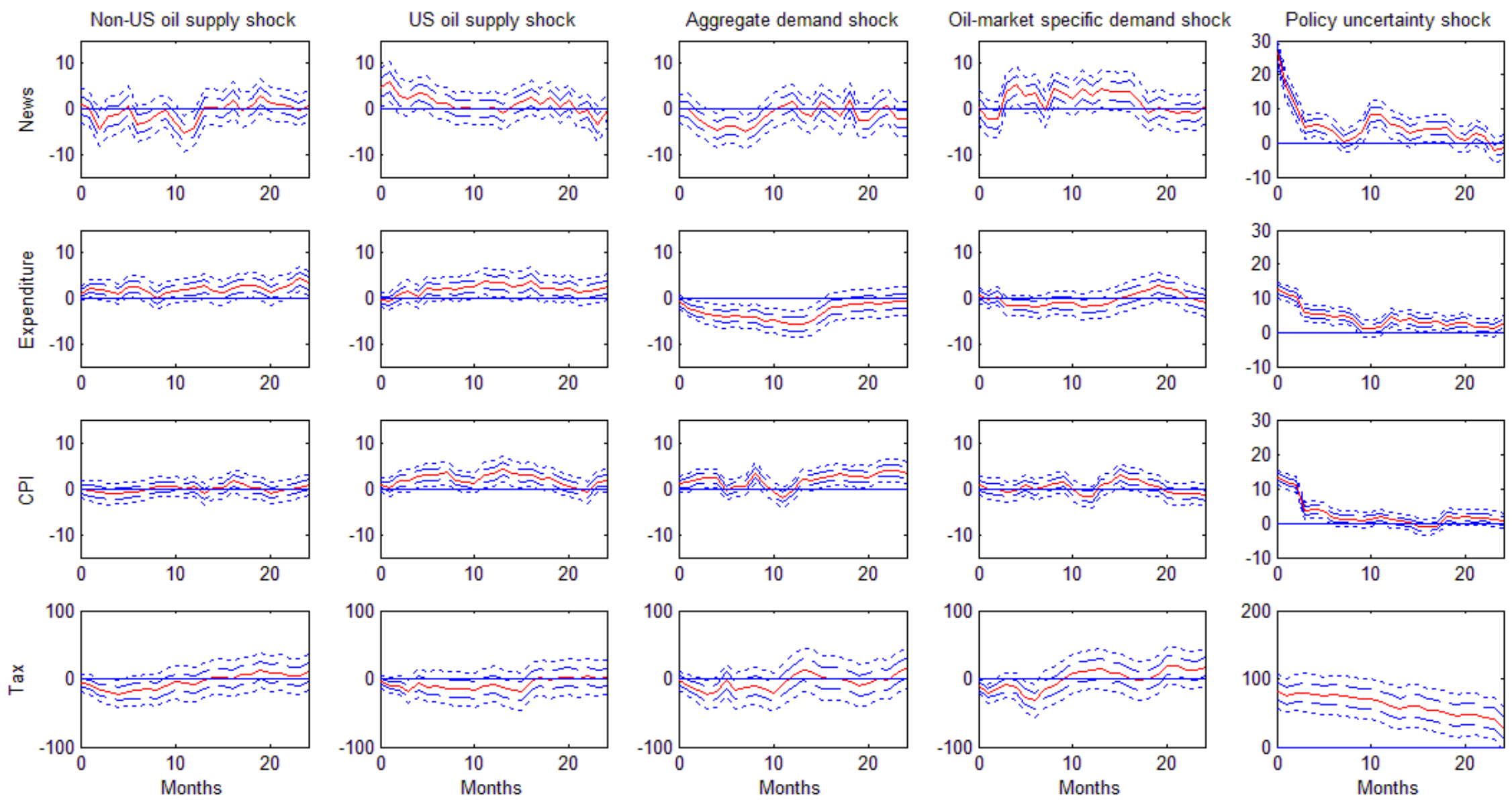

Notes: Point estimates, with one- and two-standard error bands, derived from the structural VAR model described in the text. The confidence intervals were constructed using a recursive-design wild bootstrap. 
Figure 5. The spillover plot of structural oil prices and economic policy uncertainty, 2001:1-2015:12

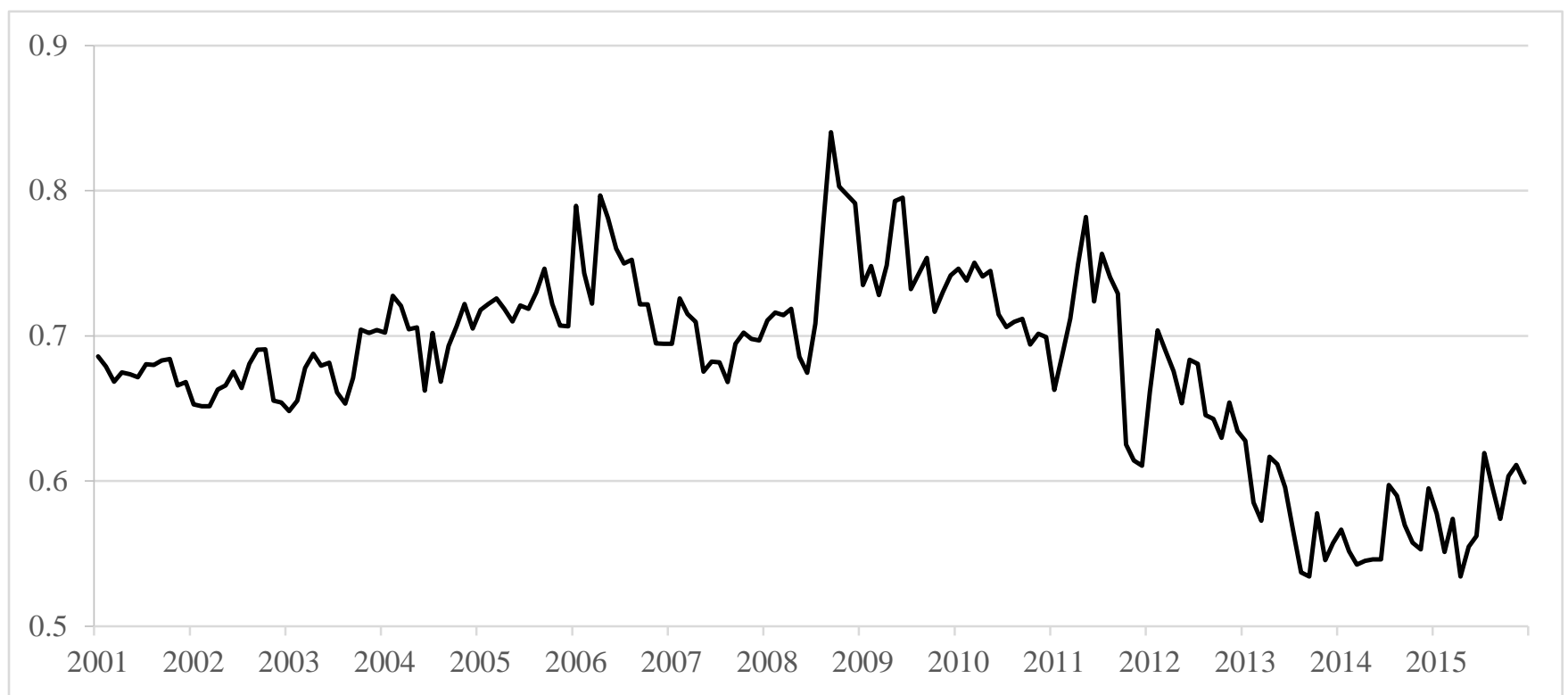

Notes: The spillover index is defined in the text as the sum of forecast error variance decomposition contributions from one variable structural shock to the other variables when the forecast horizon is 60 months, estimated using 193-month rolling windows. 
Figure 6. Contributions to the variation of economic policy uncertainty from structural shocks, 2001:01-2015:12

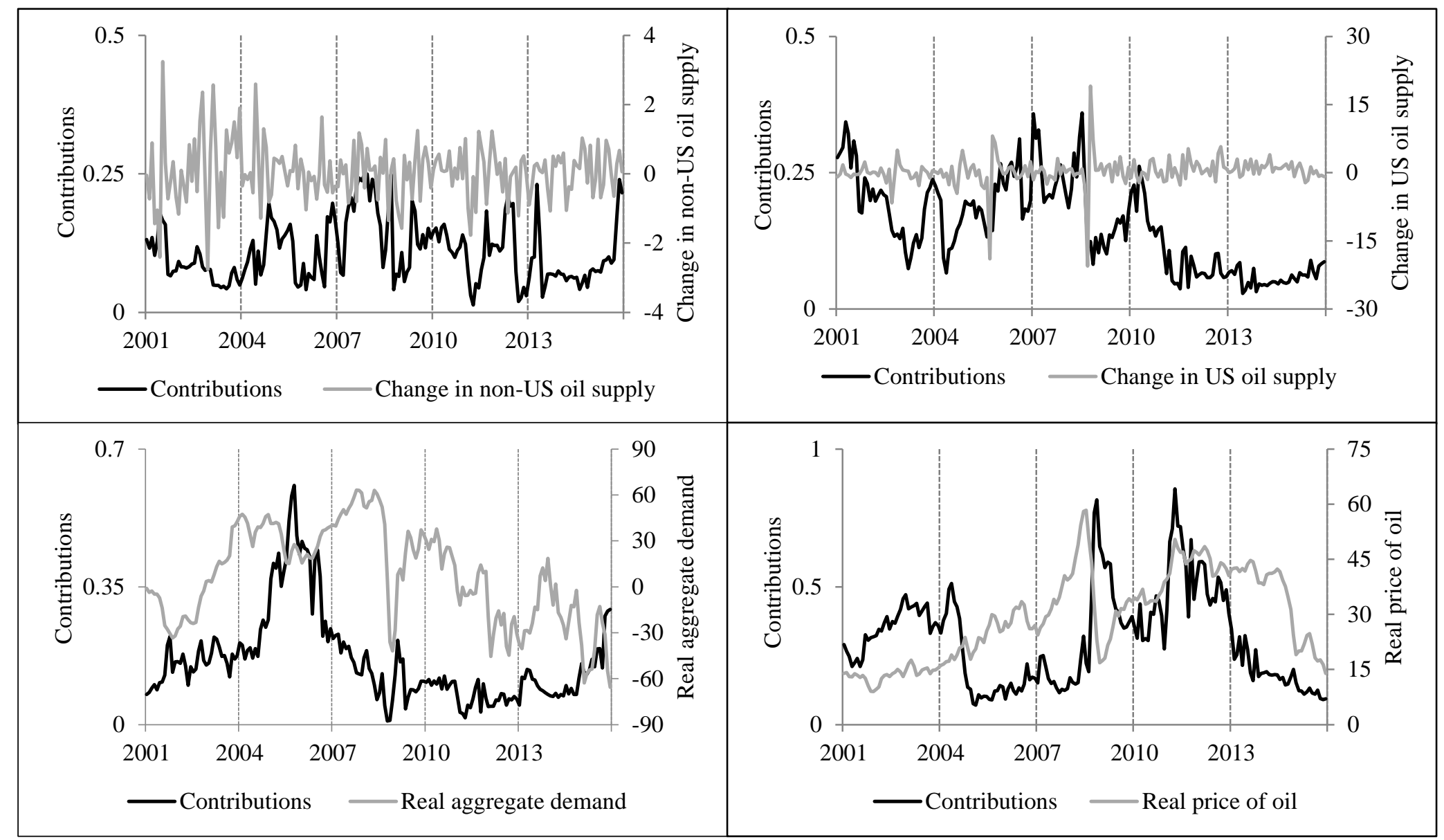

Notes: Contributions to the variation of economic policy uncertainty from non-US oil supply, US oil supply, aggregate demand, and real price of oil, 2001:012015:12, described in the text and estimated using 193-month rolling windows. 
Figure 7. Asymmetric responses of economic policy uncertainty to one-standard deviation oil price shocks

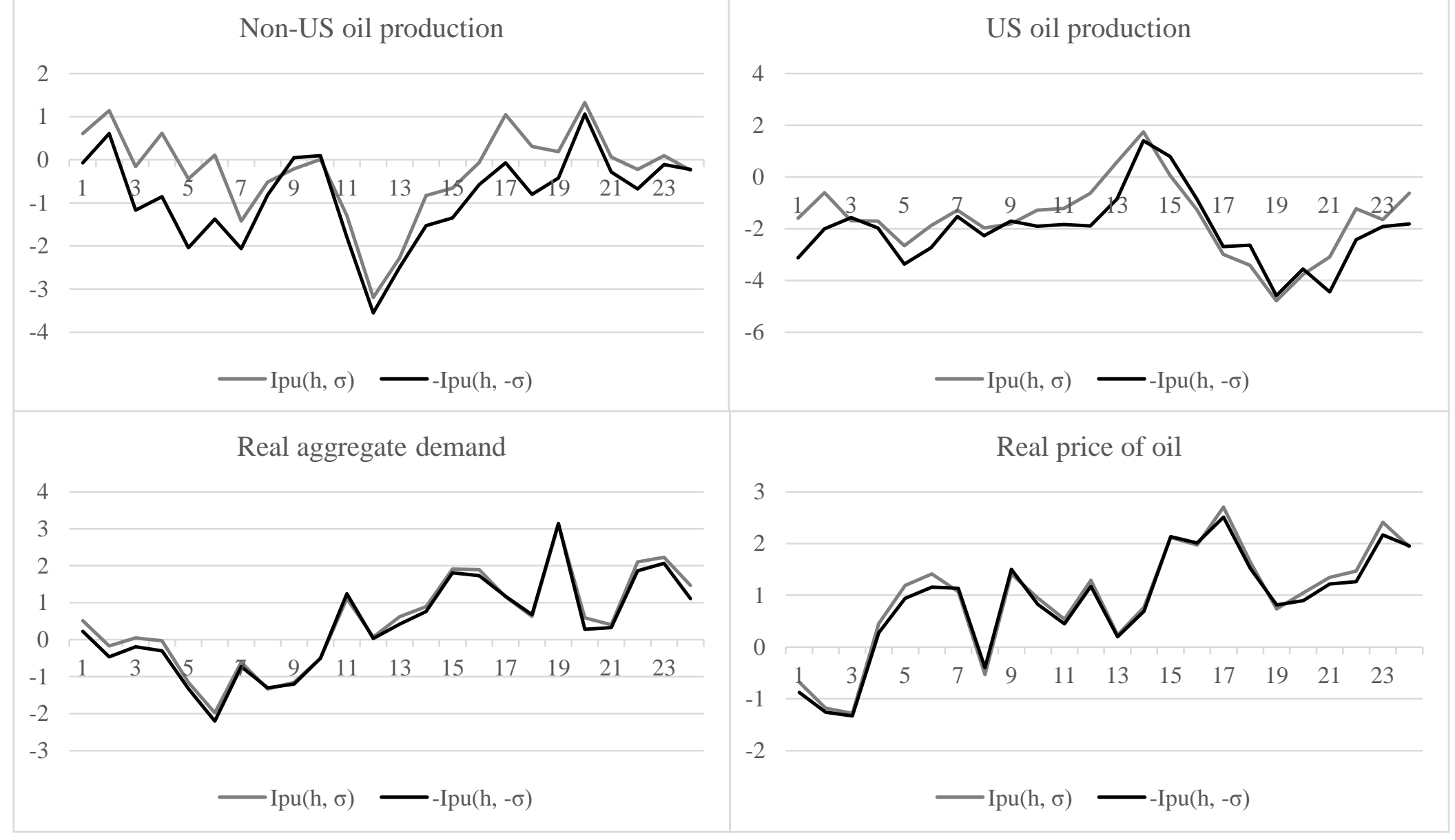

Notes: The figure shows the response of economic policy uncertainty to one standard deviation oil price shock. 
Figure 8. Asymmetric responses of policy uncertainty components to one-standard deviation oil supply shocks Non-US oil supply shock

US oil supply shock

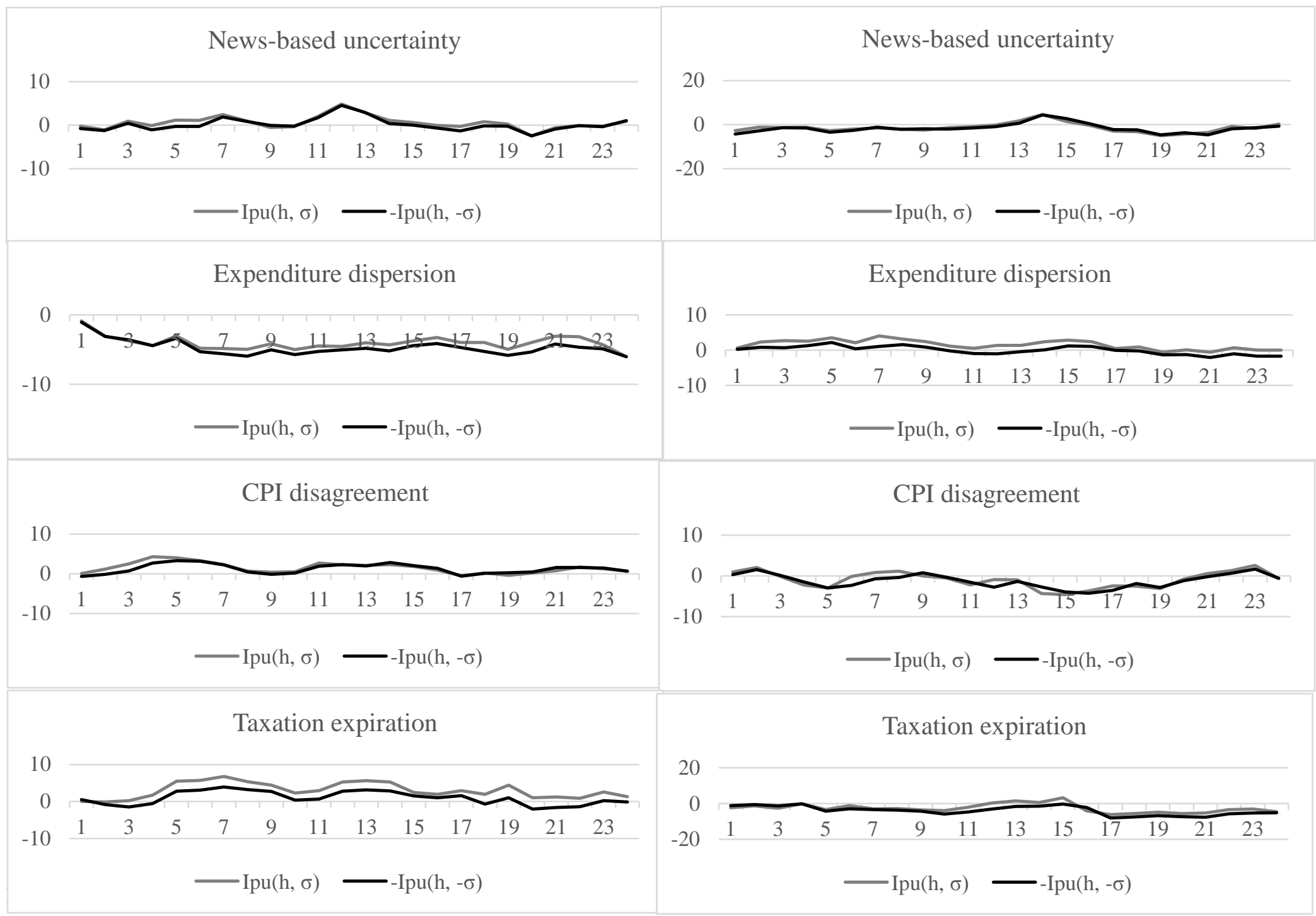


Table 1. Results of stationary test and structural change test

\begin{tabular}{|c|c|c|c|c|c|c|c|c|c|}
\hline \multirow{2}{*}{ Variables } & \multicolumn{2}{|c|}{ ADF Test } & \multicolumn{3}{|c|}{ PP Test } & \multicolumn{4}{|c|}{ KPSS Test } \\
\hline & Without trend & With trend & Without trend & Wit & trend & Withou & rend & & ith trend \\
\hline prod $^{\text {nonUS }}$ & -2.013 & -2.680 & -1.629 & -3.220 & $* *$ & 5.243 & **** & 0.684 & $* * *$ \\
\hline prod $^{\text {US }}$ & -0.784 & 1.509 & -0.594 & 1.251 & & 1.799 & *** & 0.939 & $* * *$ \\
\hline rea & -2.403 & -2.174 & -2.597 & -2.446 & & 0.826 & *** & 0.399 & $* * *$ \\
\hline rрo & -1.682 & -2.356 & -2.085 & -2.784 & & 3.164 & $* * *$ & 0.690 & $* * *$ \\
\hline $\mathrm{pu}$ & -3.167 & -3.257 & -5.300 & -5.408 & $* * *$ & 0.686 & $* *$ & 0.463 & $* * *$ \\
\hline
\end{tabular}

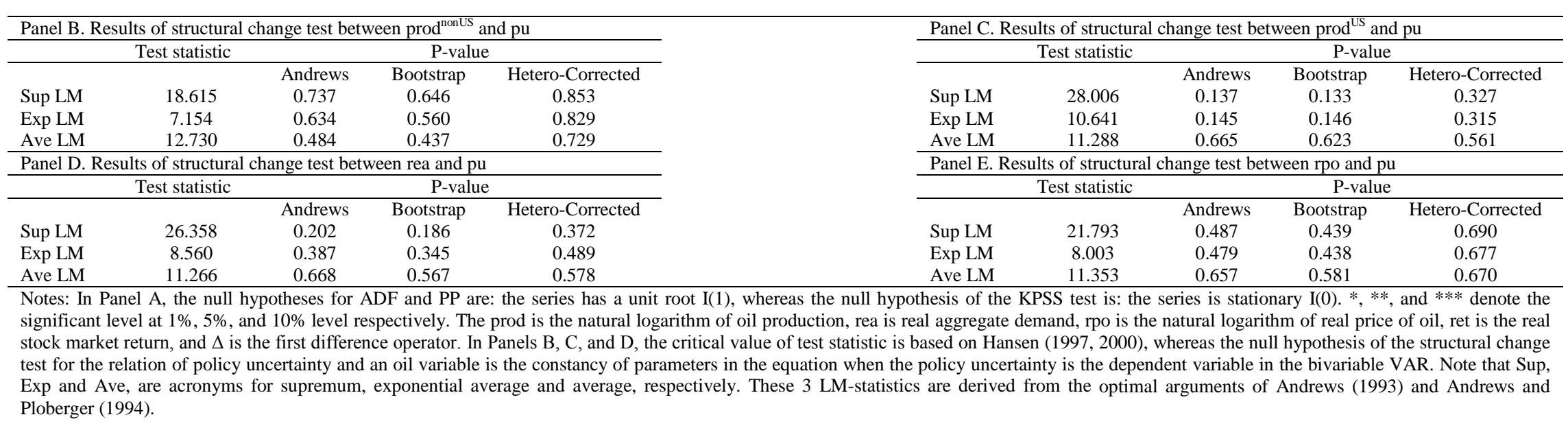


Table 2. Forecast error variance decomposition (FEVD) of economic policy uncertainty, 1985:01-2015:12

\begin{tabular}{|c|c|c|c|c|c|c|}
\hline Horizon & Non-US oil supply shock & US oil supply shock & Aggregate demand shock & Oil-market specific demand shock & \multicolumn{2}{|c|}{ Other shock } \\
\hline \multicolumn{7}{|c|}{ Panel 1. FEVD of policy uncertainty } \\
\hline 1 & 0.001 & $(0.87)$ & $(0.12)$ & $(0.12)$ & 0.968 & $(24.51)$ \\
\hline 3 & $(0.65)$ & $(1.06)$ & $(0.28)$ & $(0.24)$ & 0.923 & (16.43) \\
\hline 12 & (1.15) & $(1.40)$ & (1.37) & $(1.32)$ & 0.705 & (8.02) \\
\hline 24 & (1.09) & $(1.54)$ & (1.35) & $(1.40)$ & 0.662 & (6.61) \\
\hline 60 & $0.078 \quad(1.37)$ & (1.68) & $(1.37)$ & $(1.80)$ & 0.590 & $(6.04)$ \\
\hline \multicolumn{7}{|c|}{ Panel 2. Spillover table when forecast horizon $H=60$} \\
\hline \multicolumn{7}{|c|}{ Contributions From } \\
\hline Contributions To & $\begin{array}{l}\text { (1) Non-US oil supply } \\
\text { shock }\end{array}$ & (2) US oil supply shock & $\begin{array}{l}\text { (3) Aggregate demand } \\
\text { shock }\end{array}$ & $\begin{array}{l}\text { (4) Oil-market specific demand } \\
\text { shock }\end{array}$ & \multicolumn{2}{|c|}{ (5) Other shock } \\
\hline (1) & $0.790 \quad(16.54)$ & 0.042 & $0.048 \quad(1.95)$ & $\begin{array}{ll}0.052 & (2.33)\end{array}$ & 0.067 & $(2.66)$ \\
\hline (2) & $(2.05)$ & (11.27) & (2.60) & (2.91) & 0.057 & $(2.30)$ \\
\hline (3) & (0.63) & (1.34) & (5.64) & (1.79) & 0.074 & (1.18) \\
\hline (4) & $(0.64)$ & (1.58) & (2.98) & $(2.77)$ & 0.033 & $(0.47)$ \\
\hline (5) & (1.38) & (1.68) & (1.38) & (1.79) & 0.590 & (6.09) \\
\hline
\end{tabular}

Notes: The table shows percent contributions of demand and supply shocks in the crude oil market to the overall variability of economic policy uncertainty. The forecast error variance decomposition is based on the structural VAR model described in the text. The values in parentheses represent the absolute t-statistics when coefficients' standard errors were generated using a recursive-design wild bootstrap.

Table 3. Forecast error variance decomposition (FEVD) of economic policy uncertainty components, 1985:01-2015:12

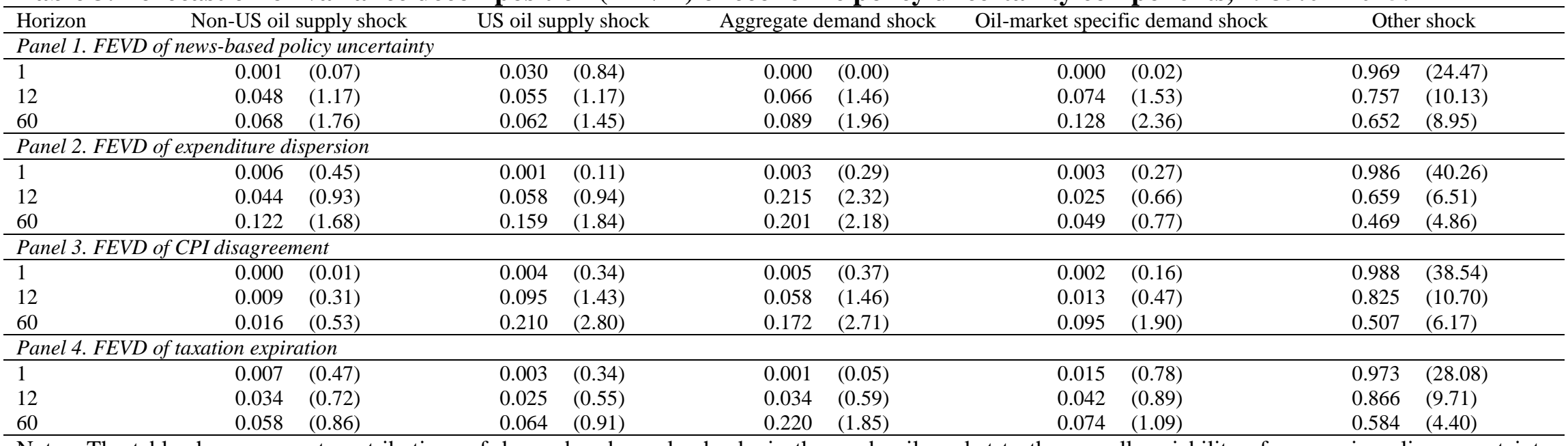

Notes: The table shows percent contributions of demand and supply shocks in the crude oil market to the overall variability of economic policy uncertainty components. The forecast error variance decomposition is based on the structural VAR model described in the text. The values in parentheses represent the absolute t-statistics when coefficients' standard errors were generated using a recursive-design wild bootstrap. 
Table 4. Testing the symmetry of policy uncertainty response $I_{p u}(h, \sigma)=-I_{p u}(h,-\sigma)$ for $h=0,1,2, \ldots, H$, to oil price shocks

\begin{tabular}{|c|c|c|c|c|}
\hline Horizon & Non-US oil production & US oil production & Real aggregate demand & Real price of oil \\
\hline \multicolumn{5}{|c|}{ Panel 1. Overall economic policy uncertainty } \\
\hline 0 & 0.001 & 0.010 & 0.002 & 0.055 \\
\hline 1 & 0.005 & 0.019 & 0.002 & 0.154 \\
\hline 3 & 0.001 & 0.056 & 0.008 & 0.170 \\
\hline 6 & 0.001 & 0.092 & 0.045 & 0.107 \\
\hline 12 & 0.001 & 0.168 & 0.003 & 0.039 \\
\hline 24 & 0.007 & 0.001 & 0.001 & 0.002 \\
\hline \multicolumn{5}{|c|}{ Panel 2. News-based policy uncertainty } \\
\hline 0 & 0.103 & 0.001 & 0.003 & 0.015 \\
\hline 1 & 0.257 & 0.002 & 0.007 & 0.018 \\
\hline 3 & 0.058 & 0.004 & 0.037 & 0.074 \\
\hline 6 & 0.012 & 0.012 & 0.092 & 0.137 \\
\hline 12 & 0.073 & 0.025 & 0.272 & 0.289 \\
\hline 24 & 0.001 & 0.001 & 0.185 & 0.025 \\
\hline \multicolumn{5}{|c|}{ Panel 3. Expenditure dispersion } \\
\hline 0 & 0.305 & 0.297 & 0.632 & 0.018 \\
\hline 1 & 0.485 & 0.001 & 0.877 & 0.058 \\
\hline 3 & 0.564 & 0.001 & 0.221 & 0.004 \\
\hline 6 & 0.512 & 0.001 & 0.425 & 0.005 \\
\hline 12 & 0.542 & 0.001 & 0.503 & 0.071 \\
\hline 24 & 0.056 & 0.001 & 0.528 & 0.001 \\
\hline \multicolumn{5}{|c|}{ Panel 4. CPI disagreement } \\
\hline 0 & 0.002 & 0.175 & 0.734 & 0.187 \\
\hline 1 & 0.001 & 0.394 & 0.802 & 0.418 \\
\hline 3 & 0.003 & 0.452 & 0.950 & 0.322 \\
\hline 6 & 0.002 & 0.037 & 0.080 & 0.194 \\
\hline 12 & 0.001 & 0.001 & 0.240 & 0.021 \\
\hline 24 & 0.001 & 0.001 & 0.062 & 0.001 \\
\hline \multicolumn{5}{|c|}{ Panel 5. Taxation expiration } \\
\hline 0 & 0.424 & 0.082 & 0.033 & 0.680 \\
\hline 1 & 0.263 & 0.183 & 0.068 & 0.001 \\
\hline 3 & 0.342 & 0.352 & 0.095 & 0.001 \\
\hline 6 & 0.612 & 0.195 & 0.011 & 0.001 \\
\hline 12 & 0.653 & 0.317 & 0.001 & 0.001 \\
\hline 24 & 0.001 & 0.001 & 0.001 & 0.001 \\
\hline
\end{tabular}

Notes: The table shows the p-vales of testing the symmetry of policy uncertainty response to oil supply- and demand-side one standard deviation shocks. The results are based on 20,000 simulations of the model. 
